Terr. Atmos. Ocean. Sci., Vol. 18, No. 2, 395-412, June 2007

\title{
Cultivation-Based Characterization of Microbial Communities Associated with Deep Sedimentary Rocks from Taiwan Chelungpu Drilling Project Cores
}

\author{
Pei-Ling Wang ${ }^{1, *}$, Li-Hung Lin ${ }^{2}$, Hon-Tsen $\mathrm{Yu}^{3}$, Ting-Wen Cheng ${ }^{2}$, Sheng-Rong Song ${ }^{2}$, \\ Li-Wei Kuo ${ }^{2}$, En-Chao Yeh ${ }^{2,4}$, Weiren Lin ${ }^{4}$, and Chien-Ying Wang ${ }^{5}$
}

(Manuscript received 7 January 2006, in final form 20 October 2006)

\begin{abstract}
The Taiwan Chelungpu Drilling Project (TCDP) has provided an unprecedented opportunity to reveal a terrestrial subsurface microbial ecosystem that has possibly experienced continuous disturbance by the arccontinental collision since $5 \mathrm{Ma}$. The drilling penetrated Pliocene-Pleistocene sedimentary rocks to a depth of $\mathbf{2 0 0 0}$ meters below the land surface (mbls) and encountered two major fault zones. Sixteen samples retrieved from the drilled cores at depths between 464 to 1451 mbls were examined to characterize microbial community structures through cultivation-based approaches. Cultivation experiments were performed with various media at temperatures ranging from 30 to $50^{\circ} \mathrm{C}$. The results indicate that fermenters and heterotrophic sulfate reducers, using complex organic carbon, were ubiquitously present in most samples. Acetate-utilizing and $\mathbf{H}_{2}$-utilizing sulfate reducers were restricted to shallower intervals along the depth profile. Iron reducers and methanogens were only cultivated in a few shallow samples. Twelve pure strains including 8 fermenters, 3 iron reducers and
\end{abstract}

1 Institute of Oceanography, National Taiwan University, Taipei, Taiwan, ROC

2 Department of Geosciences, National Taiwan University, Taipei, Taiwan, ROC

3 Institute of Zoology and Department of Life Science, National Taiwan University, Taipei, Taiwan, ROC

${ }^{4}$ Kochi Institute for Core Sample Research, Japan Agency for Marine-Earth Science and Technology, Kochi, Japan

${ }^{5}$ Department of Earth Sciences and Institute of Geophysics, National Central University, Chung-Li, Taiwan, ROC

* Corresponding author address: Prof. Pei-Ling Wang, Institute of Oceanography, National Taiwan University, Taipei, Taiwan, ROC; E-mail: plwang@ntu.edu.tw doi: 10.3319/TAO.2007.18.2.395(TCDP) 
1 sulfate reducer originally enriched at 30 or $40^{\circ} \mathrm{C}$ were isolated and identified with $16 \mathrm{~S}$ rDNA sequence analyses. They were phylogenetically affiliated with Firmicutes, Bacteriodes, Actinobacteria, and Proteobacteria in various degrees of similarity. The presence of metabolism was not correlated with lithology, depth, temperature and the appearance of fracture throughout the core. The ubiquitous appearance of fermentation and organotrophic sulfate reduction suggests that organic carbon sources were readily accessible in this deep terrestrial subsurface environment. These results infer that the foreland sedimentary strata disturbed by tectonic activities over a geological time scale might support a heterotrophy-dominated deep terrestrial subsurface microbial ecosystem.

\section{(Key words: Taiwan Chelungpu Drilling Project, Microbial community, Cultivation, Metabolism)}

\section{INTRODUCTION}

Subsurface ecosystems have been postulated to possess more than $70 \%$ of the biomass on Earth (Whitman et al. 1998). Among various subsurface environments, biomass in the terrestrial component is considered to be comparable with that in the oceanic component (Whitman et al. 1998). While sub-seafloor environments have been subject to relatively intense exploration, an exponential decline of biomass or cell density as a function of depth has been constantly observed in sediments distributed down to a depth of 1000 meters below the seafloor (Parkes et al. 2000). The biomass distribution corresponds to a successive development of metabolic zonation at which sulfate reduction is followed by anaerobic methane oxidation and methanogenesis as depth increases (D'Hondt et al. 2004). Such a stratified distribution of dominant metabolic pathway is basically consistent with diffusive substrate fluxes across highly porous media (Chapelle et al. 1995). In contrast, terrestrial subsurface environments receive far less attention and remain largely unknown in part due to the lack of appropriate access to samples at great depths. The fact that terrestrial subsurface environments are primarily composed of consolidated rocks makes sample acquisition even more difficult and costly.

Earlier studies on terrestrial subsurface microbial ecosystems focused on groundwater retrieved from shallow unconsolidated sedimentary aquifers at depths less than 1000 meters below the land surface (mbls) (Fredrickson and Onstott 2001). Geochemical and metabolic characteristics are generally consistent with those in sub-seafloor sediments with exceptions that nitrate and ferric iron appear to be more abundant in terrestrial environments and hence nitrate reduction and iron reduction are stimulated at depths above sulfate reduction zones (Lovley and Goodwin 1988). Only a few studies are related to deep consolidated or crystalline rocks (such as granite, basalt and meta-sandstone) (Stevens and McKinley 1995; Pedersen 1997; Haveman and Pedersen 1999; Chapelle et al. 2002; Cowen et al. 2003; Onstott et al. 2003; Lin et al. 2005a). The low porosity of consolidated rocks $(<1 \%)$ renders groundwater confined in fracture networks and potentially isolated from surface recharge during a geological time scale (Torgersen and Clarke 1985; Colwell 2001). While organic content associated with 
consolidated rocks is generally low and groundwater transport is extremely slow, microbial communities residing at the interface between fracture water and rock matrix have to rely on substrates derived from geological processes (Stevens and McKinley 1995). Deep terrestrial subsurface ecosystems in intra-cratonic continents are also characterized by a lessened degree of substrate exchange between different reservoirs when compared with those in shallow sedimentary aquifers (Onstott et al. 1998). The lack of ongoing tectonic processes, such as thrusting or normal faulting, reduces bulk permeability across structural features or geological strata. Solute transport would be largely restricted to the diffusion from rock matrix to fracture network (Colwell 2001; Pedersen 2001). Substrate availability, metabolic activity and community structure, therefore, can be highly heterogeneous in geographically proximal fractures, depending on water-rock interaction, groundwater residence time, and local source rock (Onstott et al. 2006). On the contrary, a deep terrestrial subsurface ecosystem would be disturbed by geological processes in a tectonic active region. Stacking of geological strata by thrusting or normal faulting would change the hydrological regime and hence affect substrate availability to certain portion of microbial communities. However, biomass distribution, community structure, and metabolic function in these terrestrial subsurface ecosystems and their relationships to geological parameters are poorly constrained.

The indigenous subsurface microbial community is difficult to recover primarily due to contamination associated with sample access. At a low biomass $\left(<10^{4} \mathrm{cell} \mathrm{g}^{-1} \mathrm{or} \mathrm{ml}^{-1}\right)$, it can be readily altered by manned activity that introduces and often stimulates the development of microbial communities with much greater biomasses (several orders of magnitude) (Fredrickson and Phelps 1996). Of various methods used for sample retrieval, surface coring provides many advantages over the others in that: (1) artificial contamination can be carefully monitored through drilling fluid and tracer; (2) microbial communities and metabolic pathways can be correlated with targeted geological features, temperature gradient, and lithology along a depth profile. The attached microbial community recovered from cores is also considered to represent the dominant component of a subsurface ecosystem that is responsible for observed geochemical signatures in groundwater (Pedersen et al. 1997).

To investigate the extent and function of indigenous, attached subsurface microbial communities associated with consolidated rocks in active tectonic environments, drilled cores with careful monitoring of artificial contamination would be required (Smith et al. 2000). The Taiwan Chelungpu Drilling Program (TCDP) has provided a unique opportunity to address these questions. The coring penetrated Pliocene-Pleistocene strata with ongoing tectonic activity in Taiwan. In this study, core samples were inoculated to various media in order to assess the cultivability of microorganisms residing within the pore space of consolidated rocks. The objective was to assess the metabolic diversity of viable microbes through the cultivationbased method and whether the cultivability of certain types of metabolism can be correlated with any geological parameter such as temperature, depth, and lithology. Four types of metabolism including iron reduction, sulfate reduction, methanogenesis and fermentation commonly observed in shallow sedimentary aquifers, were targeted for media design. Although a cultivation-based approach may unavoidably underestimate diversity, it offers direct assessment on physiological characteristics of a portion of the active microbial community. 


\section{GEOLOGICAL BACKGROUND}

Taiwan is located at the boundary between the Philippine Sea Plate and the Eurasian Plate. Continuous convergence between these two plates has resulted in an arc-continent collision that further induced the uplift of the Eocene to Pleistocene strata above the sea level along a series of east-dipping thrusts since $5 \mathrm{Ma}$ (Teng et al. 2000). The horizontal convergence has been estimated at a rate of around $80 \mathrm{~km} \mathrm{Ma}^{-1}$ since late Miocene based on plate reconstruction and GPS measurements (Suppe 1981; Yu et al. 1997). Such a substantial shortening and uplifting occurred in sedimentary strata that were originally deposited at the same horizon but later displaced from each other by tectonic movement. The shearing further enhances the development of numerous fracture zones associated with the major fault planes and, therefore, changes the hydrological circulation pattern.

The coring conducted by the TCDP was designed to retrieve cores from an active fault zone that triggered an earthquake at a magnitude of 7.6 in 1999 (Wang et al. 2000). The coring penetrated through Cholan, Chinshui, and Kueichulin formations to a depth of $2000 \mathrm{mbls}$. These Pliocene-Pleistocene strata are mainly composed of sandstone and shale in different proportions. Two major fracture zones were encountered: one located within the Chinshui formation at around $1110 \mathrm{mbls}$ and the other at the boundary between the Kueichulin formation and the underlying Cholan formations at around $1750 \mathrm{mbls}$. At depths greater than $1750 \mathrm{mbls}$, the Cholan formation was displaced underneath the Kueichuling formation by overthrusting along the deeper fracture zone. The temperature at the bottom of the borehole was $\sim 60^{\circ} \mathrm{C}$.

\section{METHODS}

\subsection{Sample Handling}

Coring was performed with a diamond-coated hollow bit at an inner diameter of $8.3 \mathrm{~cm}$. The drilling fluids consisted of water pumped from an adjacent river and bentonite and barite $\left(\mathrm{BaSO}_{4}\right)$ to reduce heat, remove rock fragments generated during pulverization, and prevent groundwater intrusion. Rhodamine dye (B-type, Sigma Aldrich, St. Louis, MO, USA) was added to the drilling fluid at a concentration of $50 \mathrm{ppm}$ (in weight) in order to monitor contamination introduced during the coring. Each core section with a maximum length of around 3 meters was retrieved to the surface using a wireless core catcher. Intact cores without lithological interclasts and structural features were chosen and sectioned into lengths of $20-30 \mathrm{~cm}$ for geomicrobiological study. The sectioned core was immediately wrapped with a sterilized aluminum foil and placed into an anaerobic box together with three Gas Paks (Becton Dickson, Franklin Lakes, NJ, USA) used for $\mathrm{O}_{2}$ absorption and $\mathrm{CO}_{2}$ production and an $\mathrm{O}_{2}$ detection strip (Becton Dickson, Franklin Lakes, NJ, USA). The anaerobic box was continuously flushed with high-grade $\mathrm{N}_{2}$ or Ar at a rate of $500 \mathrm{ml} \mathrm{min}^{-1}$ to accelerate the removal of $\mathrm{O}_{2}$. Once the $\mathrm{O}_{2}$ detection strip turned colorless for $5 \mathrm{~min}$, the anaerobic gas stream was shut off and core samples were transported back into an anaerobic glove chamber (COY Laboratory Product, Inc., USA) in the laboratory within 3 hours. 
Each core sample was split into three approximately equal portions in the anaerobic glove chamber within one day. Two of these portions were archived in either an anaerobic jar at $4{ }^{\circ} \mathrm{C}$ or freezer at $-80^{\circ} \mathrm{C}$. The rim of the third portion (potentially contaminated by drilling fluid) was peeled off with sterilized hammers and chisels. Only the central part of the core with a diameter of 2 to $3 \mathrm{~cm}$ was kept and ground into powders with a sterilized stainless steel bowl and pestle. A core sample for negative control was autoclaved at $121^{\circ} \mathrm{C}$ for $20 \mathrm{~min}$ and processed in the same procedure.

\subsection{Cultivation}

Rhodamine dye was measured for slurry consisting of ground powders and deionized water with a UV-spectrophotometer to assess the drilling-introduced contamination. For samples without detectable contamination, the powders $(\sim 1 \mathrm{~g})$ were inoculated into sterilized media $(15 \mathrm{ml})$ designed for fermentation, iron reduction, sulfate reduction and methanogenesis. The depths for sample inoculation ranged from 464 to $1451 \mathrm{mbls}$. All media were composed of basal salt solution, trace metal solution, and vitamin solution. The ingredients of the basal salt solution included $1.17 \mathrm{~g}$ of $\mathrm{NaCl}, 0.4 \mathrm{~g}$ of $\mathrm{MgCl}_{2} \times 6 \mathrm{H}_{2} \mathrm{O}, 0.3 \mathrm{~g}$ of $\mathrm{KCl}, 0.15 \mathrm{~g}$ of $\mathrm{CaCl}_{2} \times 2 \mathrm{H}_{2} \mathrm{O}$, $0.27 \mathrm{~g}$ of $\mathrm{NH}_{4} \mathrm{Cl}$, and $0.2 \mathrm{~g}$ of $\mathrm{KH}_{2} \mathrm{PO}_{4}$ per liter. The trace metal solution consisted of $1.5 \mathrm{~g}$ of nitrilotriacetic acid, $3 \mathrm{~g}$ of $\mathrm{MgSO}_{4} \times 7 \mathrm{H}_{2} \mathrm{O}, 0.5 \mathrm{~g}$ of $\mathrm{MnSO}_{4} \times 2 \mathrm{H}_{2} \mathrm{O}, 1 \mathrm{~g}$ of NaCl, $100 \mathrm{mg}$ of $\mathrm{FeSO}_{4} \times 7 \mathrm{H}_{2} \mathrm{O}, 180 \mathrm{mg}$ of $\mathrm{CoSO}_{4} \times 7 \mathrm{H}_{2} \mathrm{O}, 10 \mathrm{mg}$ of $\mathrm{CaCl}_{2} \times 2 \mathrm{H}_{2} \mathrm{O}, 180 \mathrm{mg}$ of $\mathrm{ZnSO}_{4} \times 7 \mathrm{H}_{2} \mathrm{O}$, $10 \mathrm{mg}$ of $\mathrm{CuSO}_{4} \times 5 \mathrm{H}_{2} \mathrm{O}, 20 \mathrm{mg}$ of $\mathrm{KAl}\left(\mathrm{SO}_{4}\right)_{2} \times 12 \mathrm{H}_{2} \mathrm{O}, 10 \mathrm{mg}$ of $\mathrm{H}_{3} \mathrm{BO}_{3}, 10 \mathrm{mg}$ of $\mathrm{Na}_{2} \mathrm{MoO}_{4}$ $\times 2 \mathrm{H}_{2} \mathrm{O}, 25 \mathrm{mg}$ of $\mathrm{NiCl}_{2} \times 6 \mathrm{H}_{2} \mathrm{O}$, and $0.3 \mathrm{mg}$ of $\mathrm{Na}_{2} \mathrm{SeO}_{3} \times 5 \mathrm{H}_{2} \mathrm{O}$ per liter. The vitamin solution was a mixture of $2 \mathrm{mg}$ of biotin, $2 \mathrm{mg}$ of folic acid, $10 \mathrm{mg}$ of pyridoxine- $\mathrm{HCl}, 5 \mathrm{mg}$ of thiamine- $\mathrm{HCl} \times 2 \mathrm{H}_{2} \mathrm{O}, 5 \mathrm{mg}$ of riboflavin, $5 \mathrm{mg}$ of nicotinic acid, $5 \mathrm{mg}$ of D-Ca-pantothenate, $0.1 \mathrm{mg}$ of vitamin $\mathrm{B}_{12}, 5 \mathrm{mg}$ of $\mathrm{p}$-aminobenzoic acid, and $5 \mathrm{mg}$ of lipoic acid in one liter deionized water. One liter of media was added with $10 \mathrm{ml}$ of trace metal solution and $1 \mathrm{ml}$ of vitamin solution. Electron donors and acceptors used in each desired metabolism are listed in Table 1. Resazurin at a concentration of $1 \mathrm{mg}$ per liter was added to monitor the presence of $\mathrm{O}_{2}$. A reducing agent such as $\mathrm{Na}_{2} \mathrm{~S} \times 9 \mathrm{H}_{2} \mathrm{O}$ or cystein- $\mathrm{HCl}$ at a concentration of $0.05 \%$ was used to decrease the redox potential and to remove any trace amounts of $\mathrm{O}_{2}$. Ingredients for media were mixed thoroughly with $\mathrm{pH}$ adjusted to $\sim 7.2$. The resultant solution was boiled and dispensed into borosilicate vials under anoxic conditions. Vials were sealed with butyl rubber stoppers and autoclaved at $121^{\circ} \mathrm{C}$ for $20 \mathrm{~min}$. Headspace was flushed with desired $0.2 \mu \mathrm{m}$-filtered gases (Table 1) for $5 \mathrm{~min}$ before use. Incubation temperature was set at $30^{\circ} \mathrm{C}, 40^{\circ} \mathrm{C}$ and $50^{\circ} \mathrm{C}$ for samples retrieved from different depths (Table 2). Parallel negative control without inoculation was performed.

Enrichments were constantly checked with a phase-contrast microscope and assayed with aqueous or gas chemistry. DAPI staining technique with a fluorescence microscope was also applied for enrichments without distinguishable or dividing cells under a phase-contrast microscope. Fermentation was detected by an increase of cell density. Positive reduction of ferric iron to ferrous iron was indicated by an increase in cell density and a color change from orange to colorless. Concentrations of ferrous iron were measured with ferrozine assay (Lovley and Phillips 1987). Enrichments with an increase in cell density but no change of color were 
attributed to positive fermentation given that the iron reduction medium consisted of citrate and lactate that can be used by fermenters. Positive sulfate reduction was reflected in an increase in cell density and substantial formation of $\mathrm{H}_{2} \mathrm{~S}$, which was precipitated as $\mathrm{ZnS}$ while the enrichment was mixed with $\mathrm{Zn}$-acetate solution. Methanogenesis was indicated by an increase in cell density with the production of methane over time. Once positive growth was confirmed, the enrichment was transferred to a fresh media with a dilution factor of $1: 10$ to reduce the contribution of original substrate derived from rocks. Metabolic capability was ascertained after at least 3 transfers.

\subsection{Pure Strain Isolation}

Pure cultures were obtained by plating or serially diluting the positive enrichment cultures. After at least 5 transfers, enrichment was spread in $1.5 \%$ agar plates with various dilution factors and incubated under the same conditions until individual colonies were formed. Single colonies were picked up with sterilized pipette tips and re-suspended in liquid media to obtain pure strains. Pure strains were repeatedly purified in $1.5 \%$ agar plates. The purity of pure strains obtained by serial dilution was confirmed by restriction fragment length polymorphism patterns for clone PCR products obtained from at least 20 colonies in the clone library.

Table 1. Summary of ingredients used in the media.

\begin{tabular}{lllll} 
Target metabolism & Electron donor & Electron acceptor & Headspace gas & Others \\
\hline Fermentation & $\begin{array}{l}0.1 \% \text { peptone, } 0.1 \% \text { yeast extract, } 0.1 \% \\
\text { tryptone }\end{array}$ & $100 \% \mathrm{~N}_{2}$ & $\begin{array}{l}0.05 \% \\
\text { sulfide }\end{array}$ \\
$\begin{array}{llll}10 \mathrm{mM} \text { lactate, } \\
\text { Iron reduction }\end{array}$ & $\begin{array}{l}10 \mathrm{mM} \text { ferric } \\
\text { citrate }\end{array}$ & $\begin{array}{l}10 \% \mathrm{H}_{2}, 10 \% \mathrm{CO}_{2}, \\
80 \% \mathrm{~N}_{2}\end{array}$ & \\
$\begin{array}{l}\text { Sulfate reduction }- \\
\text { complex organics }\end{array}$ & $\begin{array}{l}0.1 \% \text { yeast, } 10 \\
\mathrm{mM} \text { lactate }\end{array}$ & $\begin{array}{l}20 \mathrm{mM} \text { sodium } \\
\text { sulfate }\end{array}$ & $100 \% \mathrm{~N}_{2}$ & $\begin{array}{l}0.05 \% \\
\text { sulfide }\end{array}$ \\
$\begin{array}{l}\text { Sulfate reduction }- \\
\text { acetate }\end{array}$ & $10 \mathrm{mM}$ acetate & $\begin{array}{l}20 \mathrm{mM} \text { sodium } \\
\text { sulfate }\end{array}$ & $100 \% \mathrm{~N}_{2}$ & $\begin{array}{l}0.05 \% \\
\text { sulfide }\end{array}$ \\
$\begin{array}{l}\text { Sulfate reduction }- \\
\mathrm{H}_{2}\end{array}$ & $10 \% \mathrm{H}_{2}$ & $\begin{array}{l}20 \mathrm{mM} \text { sodium } \\
\text { sulfate }\end{array}$ & $\begin{array}{l}10 \% \mathrm{H}_{2}, 10 \% \mathrm{CO}_{2}, \\
80 \% \mathrm{~N}_{2}\end{array}$ & $\begin{array}{l}0.05 \% \\
\text { sulfide }\end{array}$ \\
Methanogenesis & $\begin{array}{l}10 \% \mathrm{H}_{2}, 10 \mathrm{mM} \\
\text { acetate }\end{array}$ & $\begin{array}{l}20 \mathrm{mM} \text { sodium } \\
\text { bicarbonate, } 10 \%\end{array}$ & $\begin{array}{l}10 \% \mathrm{H}_{2}, 10 \% \mathrm{CO}_{2}, \\
80 \% \mathrm{~N}_{2}\end{array}$ & $\begin{array}{l}0.05 \% \\
\text { cystein- } \mathrm{HCl} \\
\text { or } 0.05 \% \\
\text { sulfide }\end{array}$ \\
\hline
\end{tabular}

*All media consisted of basal salt solution, trace metal solution, and vitamin solution. 
Table 2. Summary of incubation conditions and cultivation results.

\begin{tabular}{|c|c|c|c|c|c|c|c|c|}
\hline \multirow{2}{*}{ Sample No." } & \multirow{2}{*}{ Lithology } & \multirow{2}{*}{$\begin{array}{c}\mathrm{T} \\
\left({ }^{\circ} \mathrm{C}\right)\end{array}$} & \multicolumn{6}{|c|}{ Media type $^{\# \&}$} \\
\hline & & & $\mathbf{F}$ & IR & SR-comp & SR-H & SR-Ac & $\mathbf{M}$ \\
\hline TCDP464 & Sandstone & 30 & + & + & + & n.d & n.d & n.d. \\
\hline TCDP545.2SS & Sandstone & 30 & + & + & + & + & + & + \\
\hline TCDP545.2SH & Shale & 30 & + & n.d. & + & n.d. & n.d. & n.d. \\
\hline TCDP545.6 & Sandstone & 30 & + & n.d. & + & + & + & n.d \\
\hline TCDP690 & Siltstone & 40 & + & n.d. & + & n.d. & + & n.d. \\
\hline TCDP694 & Sandstone & 40 & + & n.d. & n.d & n.d. & n.d & + \\
\hline TCDP694FG & Gouge & 40 & + & n.d. & + & + & n.d & + \\
\hline TCDP739 & Siltstone & 40 & + & n.d. & + & + & n.d & n.d. \\
\hline TCDP829 & Shale & 40 & + & n.d. & + & n.d. & + & n.d. \\
\hline TCDP833 & Siltstone & 40 & n.d & n.d. & + & + & n.d & n.d \\
\hline TCDP887 & Siltstone & 40 & + & n.d. & + & n.d. & n.d & n.d. \\
\hline TCDP1033 & Shale & 40 & + & n.d. & + & n.d & n.d & n.d. \\
\hline TCDP1187 & Shale & 40 & + & n.d. & + & n.d & + & n.d. \\
\hline TCDP1284 & Siltstone & 40 & + & n.d. & n.d & + & + & n.d. \\
\hline TCDP1450 & Siltstone & 50 & + & n.d. & n.d & n.d. & + & n.d. \\
\hline TCDP1451 & Sandstone & 50 & + & n.d & n.d & + & n.d & n.d \\
\hline
\end{tabular}

"The number adjacent to TCDP in the column of "Sample No." represented the depth of the sample.

${ }^{\#}$ Media type: F: fermentation, M: methanogenesis, IR: iron reduction, SR-comp: sulfate reduction with complex organic carbon as electron donors, $\mathrm{SR}-\mathrm{H}_{2}$ : sulfate reduction with $\mathrm{H}_{2}$ as an electron donor, SR-Ac: sulfate reduction with acetate as an electron donor.

\& +: positive; n.d.: not distinguishable. 
16S rRNA genes for pure strains were used to characterize their phylogenetic relationships with those deposited in Genbank (www.ncbi.nih.gov) and Ribosomal Database Project (rdp.cme.msu.edu, RDP 9 Release) (Cole et al. 2003). Genomic DNA was extracted using MoBio UltraClean Soil Kit (MoBio, Carlsbad, CA, USA) according to the manufacturer's instruction. Bacterial 16S rRNA genes were PCR-amplified with primers of 27F (5'-AGA GTT TGA TCM TGG CTC AG-3') with 1492R (5'-CGG TTA CCT TGT TAC GAC TT-3') (Lane 1991). Each PCR cycle (total 30 cycles) consisted of a 30 -sec denaturation step at $94^{\circ} \mathrm{C}$, a 45 -sec annealing step at $54^{\circ} \mathrm{C}$, and a 2-min elongation step at $72^{\circ} \mathrm{C}$. Each PCR reaction (total of $50 \mu \mathrm{l}$ ) contained $5 \mu \mathrm{l}$ of 10X PCR buffer, $4 \mu \mathrm{l}$ of $2 \mathrm{mM}$ deoxynucleioside, $4 \mu \mathrm{l}$ of $25 \mathrm{mM}$ $\mathrm{MgCl}_{2}, 1 \mu \mathrm{l}$ of each $25 \mu \mathrm{M}$ primer, and $1 \mathrm{U}$ of Ex Taq (Takara, Shiga, Japan). PCR products were checked in $1.0 \%$ agarose gel stained with SYBR dye (Molecular Probes, Carlsbad, CA, USA). Positive PCR products were further purified using a MoBio PCR cleaning kit (MoBio, Carlsbad, CA, USA) and sequenced using an ABI 377 sequencer (Applied Biosystems, Foster, CA, USA). Sequences for $16 \mathrm{~S}$ rRNA genes were compared and aligned with those in Genbank and RDP databases. A distances matrix for neighbor joining was calculated according to the algorithm of Jukes and Cantor (Felsenstein 1993) using the Bioedit program (Hall 1999). Neighbor-joining analyses were performed on the basis of $\sim 1000$ homologous bases.

\section{RESULTS}

Sixteen sets of inoculation were performed for six months after core samples were retrieved. A summary of cultivability for different samples is listed in Table 2. None of cultivable metabolisms has been detected in negative controls. Twelve isolates were obtained and characterized by their 16S rRNA gene sequences with their close affiliation (Table 3).

Fermentation bacteria appeared to be enriched positively for most inoculations. The incubation temperature for cultivated fermenters spanned from mesophilic to thermophilic range adopted from possible in situ temperatures $\left(30\right.$ to $50^{\circ} \mathrm{C}$ ) (Table 2). Several morphotypes, including cocci, short rod, and long rod, were observed. Six strains were isolated from the enrichment for the sample at 545.2 mbls. $16 \mathrm{~S}$ rRNA gene sequences for these strains exhibited a close affiliation with Clostriduim intestinale, Propionibacterium propionicum, and some uncultured bacterium clone within Firmicutes, Bacteriodes, and Actinobacteria (Table 3). Fermenters were also enriched from iron reducing medium by using citrate and/or lactate as energy and organic sources without reducing ferric iron (no color change was observed). They appeared to be composed of cocci only, no matter the depth of the sample or incubation temperature. One of fermentative strains was isolated from the sample at $545.6 \mathrm{mbls}$. The $16 \mathrm{~S}$ rDNA sequence of this fermenter cultivated in the iron reducing medium was a relative of Propionibacterium acnes within Actinobacteria at a similarity of $99 \%$ (Table 3). Sulfate reducing medium with yeast extract as an energy source yielded a fermentative isolate from 877 mbls; and its $16 \mathrm{~S}$ rDNA sequence was related to an uncultured bacterium clone within Actionbacteria at a similarity of $99 \%$ (Table 3).

Positive iron reduction enrichments were obtained from two shallow depth intervals (464 and 545.2 mbls) (Table 2) with totally three strains isolated (Table 3). These strains exhibited two physiological characteristics with one producing brownish mineral precipitates during 
Wang et al.

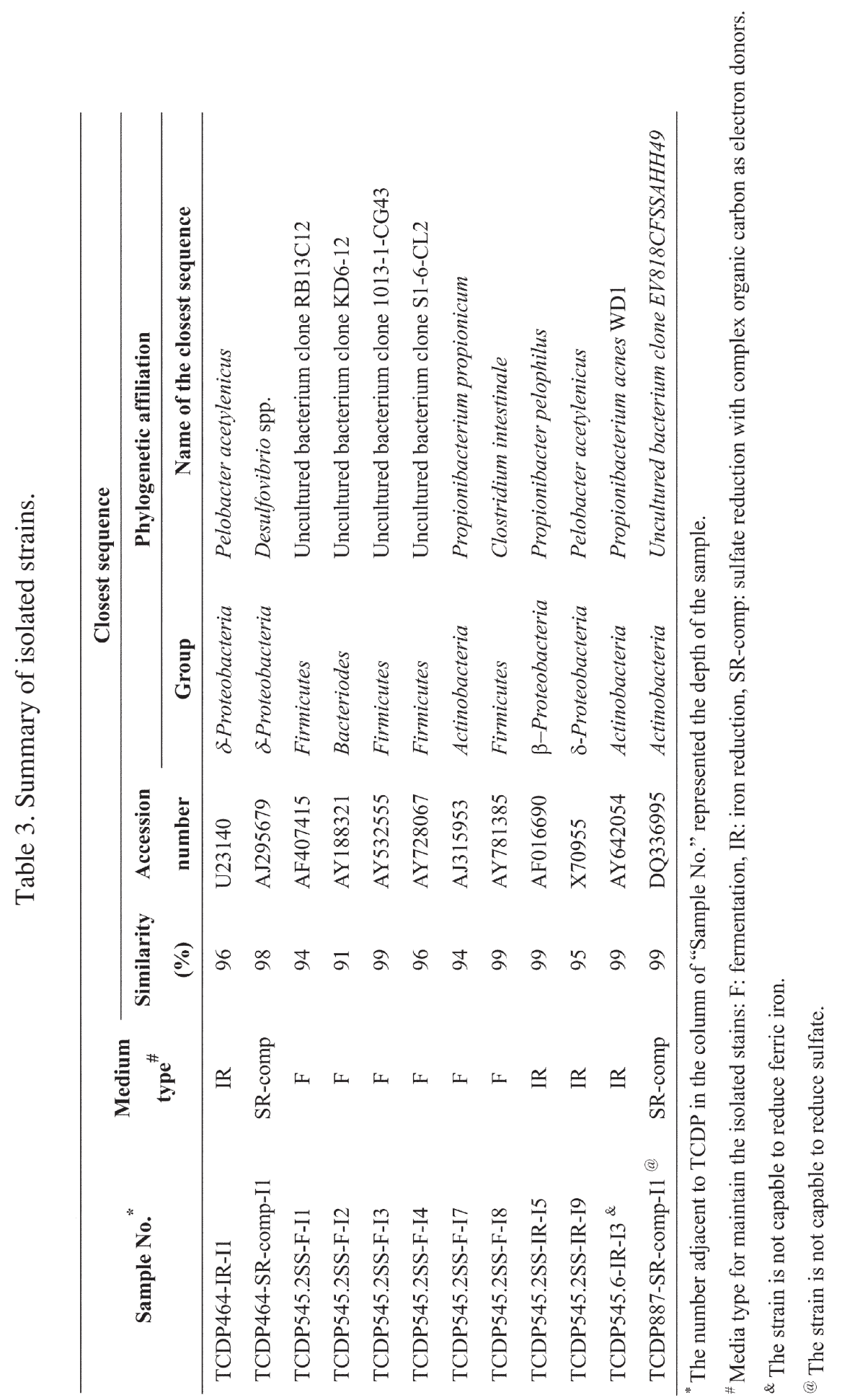


incubation and the other one not generating any mineral precipitate. Phylogenetic analyses of $16 \mathrm{~S}$ rDNA indicated that only two different sequences in accordance with their physiological characteristics were obtained. One strain capable of generating mineral precipitates was related to Propionibacter pelophilus (Meijer et al. 1999) at a similarity of 99\%, whereas two strains not producing mineral precipitates during incubation were affiliated with Pelobacter acetylenicus (Schink 1985) at a similarity of $95-96 \%$ (Table 3). Both strains also grew in the fermentation medium.

Organotrophic sulfate reduction using yeast extract and/or lactate was positively enriched in most samples (Table 2). The incubation temperature also varied from the mesophilic to thermophilic range. One strain was further isolated from the enrichment for the sample at 464 mbls. Its $16 \mathrm{~S}$ rDNA sequence exhibited a very close affiliation (at a similarity of 99\%) with Desulfovibrio spp. within $\delta$-Proteobacteria. Acetate-utilizing and $\mathrm{H}_{2}$-utilizing sulfate reducers were cultivable in some samples, but they grew slowly and showed lower cultivability than coexisted sulfate reducers using complex organic carbon as electron donors.

Methanogens were enriched from two depth intervals (545.2 and 694 mbls) (Table 2). The cultivability for these enrichments was much lower than the other metabolisms. It generally took more than 2 months to observe significant production of methane. During six months of cultivation, methanogenesis was not detected for samples at the deeper region.

\section{DISCUSSION}

\subsection{Substrate Source for Viable Microbes}

Our cultivation work indicated a ubiquitous presence of heterotrophic fermenters and sulfate reducers to the depth of $1451 \mathrm{mbls}$. Autotrophic sulfate reducers and methanogens, however, were limited to certain depth intervals. The fact that heterotrophic fermenters and sulfate reducers required organic carbon for energy yield metabolisms suggests that organic matters associated with sedimentary particulates during deposition provided a direct energy source for this microbial ecosystem. Fermenters degraded refractory carbon molecules into smaller carboxylic acids and $\mathrm{H}_{2}$ for heterotrophic and autotrophic metabolisms, respectively (Jackson and Mclnerney 2002). Since the sedimentary strata here are marine sediments in their origins, sulfate reducers may reply upon seawater sulfate preserved within pore space. Alternatively, re-oxidation of pyrite or iron mono-sulfide to sulfate by episodic oxygen penetration associated with tectonic processes may provide another source for sulfate reduction. Sporadic presence of iron reduction relied on ferric oxyhydroxide or goethite coated on the surface of sediments (Fredrickson et al. 1998). The abundance of ferric iron-bearing minerals may be low or limited in a local scale to inhibit the prevalence of iron reduction. Two possible methanogenic pathways, including $\mathrm{H}_{2}$-utilization and acetate fermentation may persist in samples investigated. The most likely source for $\mathrm{H}_{2}$ and acetate in sedimentary environments is derived from the fermentation of organic carbons (Boone et al. 1989). $\mathrm{H}_{2}$-utilization methanogenesis, however, requires additional bicarbonate as an electron acceptor (Zinder 1993). This bicarbonate can be either produced from dissolution of fossils or carbonate minerals 
filled within fracture surfaces or the byproduct of fermentation. The lack of methanogenesis for samples at the deeper region may be due to its low activity in limited cultivation time or the depletion of $\mathrm{H}_{2}$ /acetate sources through termination of $\mathrm{H}_{2}$ /acetate-producing mechanisms or competition by other $\mathrm{H}_{2}$ /acetate utilizers.

The metabolic pathways inferred from cultivation results were generally consistent with those from $16 \mathrm{~S}$ rDNA analyses of the environmental DNA extracted from the same set of samples. For the samples at depths shallower than $1300 \mathrm{mbls}$, a single OTU (operational taxonomic unit) with a sequence highly similar (99\%) with Janthinobacterium spp. dominated over the other OTUs (at least 60\%) (Chang 2005). Given the high similarity, this OTU may share the same physiological characteristics with that of Janthinobacterium spp., which is capable of heterotrophically fermenting complex organic carbon or reducing nitrate (Zhang et al. 2005). The $16 \mathrm{~S}$ rDNA analysis, however, didn't detect any sequence belonging to the iron reducer group or sulfate reducer group, such as Geobacter, Geothrix, Desulfuromonas, and Desulfovirbrio within $\delta$-Proteobacteria, Thermodesulfobacterium, and Archaeoglobus. Possible explanation for this is that viable iron reducers and sulfate reducers are minor in the whole community, and hence not detected through molecular screening. More detailed FISH (fluorescence in-situ hybridization) are warranted to verify whether the fermenters enriched in the culture experiments are related with those detected in the environmental DNA.

\subsection{Switch between Iron Reduction and Fermentation}

Isolated iron reducing strains possessed $16 \mathrm{~S}$ rDNA sequences affiliated with Propionibacter pelophilus within $\beta$-Proteobacteria and Pelobacter acetylenicus. within $\delta$-Proteobacteria (Table 3). Of these two closest strains, Propionibacter pelophilus is capable of fermenting sugars to propionate with tolerance to the exposure of oxygen (Meijer et al. 1999). No iron reduction and sulfate reduction has been reported for this strain. A number of Pelobacter strains were firstly isolated from fermentation of various organic substrates with production of propionate and acetate (Schink and Stieb 1983; Schink 1984; Schink 1985). Subsequent tests have shown that they are capable of reducing ferric iron (dissolved Fe-citrate or iron oxyhydroxide), elemental sulfur and/or sulfate with completely mineralizing organic carbon to carbon dioxide (Lonergan et al. 1996). The fact that our isolates could reduce dissolved ferric iron and ferment complex organic carbon indicates that these two strains could adjust their physiological capability upon encountering various environments. When the ferric iron is in absence, these two strains conserve energy through incomplete degradation of organic carbon to carboxylic acids and bicarbonate (Boone 1984). Upon the presence of ferric oxyhydroxides, carboxylic acids are completely transformed to carbon dioxide with the reduction of ferric iron (Lovley and Anderson 2000). Whether these two isolates possess more metabolic capacity by reducing other electron acceptors warrants further experimentation.

\subsection{Correlation with Geological Parameters}

Our enrichment results suggest that the type and diversity of cultivable metabolisms did not correlate well in the whole-core scale with lithology, depth (from 464 to $1451 \mathrm{mbls}$ ), and 
the presence of the major fault zone. Limited correlations, however, were revealed for certain sample sets.

The variation of lithology is directly related to porosity and pore throat, and hence affects the transport property of substrate and microorganisms between lithological units (Colwell 2001). Mercury porosimetry analyses of TCDP retrieved cores indicated that the sandstone possessed porosities ranging between $13 \%$ and $16 \%$ and pore throats clustering at $\sim 10 \mu \mathrm{m}$, whereas the siltstone and shale had porosities ranging between $3 \%$ and $6 \%$ and pore throats distributed at $\sim 0.2$ and $\sim 0.08 \mu \mathrm{m}$, respectively (Lin et al. 2005b). The porosity and pore throat are independent from depths for the same lithology (Lin et al. 2005b). Since the porosity of sandstone is greater than those of siltstone and shale by a factor of 2 to 4 , the diffusion flux of substrates in sandstone would be enhanced with the same magnitude $(\mathrm{J}=-\phi \mathrm{D} \partial \mathrm{C} / \partial \mathrm{z}$ where $\mathrm{J}$ is the diffusive flux, $\mathrm{C}$ is the concentration of solutes, $\mathrm{D}$ is the diffusion coefficient for a given solute, $\phi$ is effective porosity, and $\mathrm{z}$ is the distance from a reference point) (Lin et al. 2005a). It would be expected that microorganisms residing within sandstone could have access to a greater flux of aqueous substrate than those within siltstone or shale. Such a porosity effect was only observed in the sandstone-shale samples from $545.2 \mathrm{mbls}$. In sandstone, all tested metabolisms were positively enriched, whereas in shale only fermentation and organotrophic sulfate reduction (using complex organic carbon) enrichments were obtained (Table 2).

The increasing depth corresponds to increasing temperature along the geothermal gradient. Within the depth range investigated, the temperature is expected to increase from 25 to $50^{\circ} \mathrm{C}$, a temperature range within which a transition from mesophilic to thermophilic communities could survive. While the cultivated metabolism primarily consisted of fermentation and heterotrophic sulfate reduction, the temperature obviously didn't stimulate or inhibit either of these two metabolisms. The appearance of other metabolisms we examined has no correlation with depth, but both iron reduction and methanogenesis cannot be enriched at the deeper region.

Fracture zones have been considered to act as a channel for fluid circulated either downward or upward (Haneberg et al. 1999). The substrate flux within the fracture zone would be greater than that in the matrix, supporting microbial populations at a high activity and/or diversity. More cultivated metabolisms derived from the thin layer of fault gauge than those from its host rocks at $690 \mathrm{mbls}$ were consistent with this general consideration (Table 2). The diversity of cultivable metabolisms for samples adjacent to the Chelungpu fault zone located at depths ranging from 1100 to 1220 mbls (Hung et al. 2007; Song et al. 2007; Yeh et al. 2007), however, neither increased nor decreased significantly. It seemed to suggest that either the fluid circulation was limited within a relatively narrow range or the fault zone had no effect on enhancing the diversity of metabolisms. Instead of relying upon substrates accompanying fluid circulation, microbial communities acquired their substrates preserved within the pore space or associated with sedimentary particulates. Alternatively, the fluid brought in chemistry similar to pore water. Therefore, no additional type of electron donor or acceptor is provided to stimulate any specific metabolism for samples near the fracture zone.

\subsection{Coexistence of Multiple Terminal Electron Accepting Processes}

All the tested metabolisms were shown to be positive for the sample at $545.2 \mathrm{mbls}$. Iron 
reduction and sulfate reduction coexisted in the sample at 464 mbls. Methanogenesis and sulfate reduction also coexisted in the fault gauge sample at $690 \mathrm{mbls}$ (TCDP690FG). The concomitant presence of iron reducers, sulfate reducers and methanogen is contradictory to the conventional observation for shallow aquifers in that iron reduction, sulfate reduction, and methanogenesis developed successively along the groundwater transport pathway (Chapelle et al. 1995). Such a discrete metabolic and geochemical zonation resulted from the interplay of fermentation and terminal electron accepting processes (Lovley and Goodwin 1988). Because organic carbon is generally limited in shallow aquifer ecosystems in comparison with terminal electron acceptors, microorganisms with a certain metabolism have to maximize the utilization efficiency of bio-available organic acids (such as acetate) or $\mathrm{H}_{2}$ produced by heterotrophic fermentation (McMahon and Chapelle 1991). The competition for organic acids or $\mathrm{H}_{2}$, therefore, regulates the distribution of each terminal electron accepting process and geochemical characteristics along the groundwater flow path. Metabolic reaction with more free energy yield decreases organic acids or $\mathrm{H}_{2}$ to a threshold level below which other metabolic reactions with less free energy yield would not be able to acquire enough substrate for minimum maintenance (Hoehler et al. 2001). Instead of being electron donor (presumably organic carbon) limited, the deep subsurface ecosystem might be limited by electron acceptors (Fredrickson and Onstott 2001). The stoichiometric excess of electron donor relative to electron acceptor would reverse the sequence of metabolism in the porous medium mentioned above (Coates and Achenbach 2002). While methanogenesis would be the dominant metabolism near the source of organic carbon, sulfate reduction and iron reduction zones would sequentially develop as the distance from carbon source increases (Smith 2002). This is because all electron acceptors, but bicarbonate, are depleted near the locus of organic carbon. Methanogenesis becomes advantageous over the other metabolisms. Such a reverse sequence of metabolic zonation, however, is still not consistent with the coexistence of multiple metabolisms for a given depth in our samples.

Possible explanations of the coexistence of multiple metabolisms here are twofold. The cultivated members only represented a small portion of the active population and might not necessarily be the dominant metabolism. Because the designed media were selective to certain metabolisms, any viable microorganism capable of utilizing the provided substrate could be enriched. Our results cannot conclusively infer that these cultivated members were numerically or metabolically dominant over the others, even the dominant member intuitionally could be easily cultivated. Therefore, the sequential appearance of various metabolisms shown in other subsurface ecosystems cannot possibly be evaluated with cultivation-based analyses only. The coexistence of multiple metabolisms observed here should not be interpreted further. Alternatively, the coexistence of multiple metabolisms may result from a microbial ecosystem without severe competition in nutrients. It's possible that microorganisms were universally distributed within the pore space that may not be interconnected to each other physically (Lin et al. 2005b). Each pore space harbored microorganisms capable of diverse metabolisms. Because electron donor is not a limiting factor, microorganisms trapped within the pore space would utilize any electron acceptor available within the pore space. Our current analysis doesn't allow for rejection of any speculation. Molecular screening of community structures based on the 16S rRNA gene variation and functional gene is warranted for future evaluation. 


\section{CONCLUSIONS}

Sixteen cored samples retrieved by TCDP were analyzed with cultivation-based methods to reveal the metabolic diversity of microorganisms inhabiting a deep terrestrial subsurface environment composed of sedimentary strata with ongoing tectonic activities. The cultivation experiments indicated that mesophilic and thermophilic fermenters and organotrophic sulphate reducers (using complex organic carbon and acetate) dominated over the other investigated metabolisms and multiple terminal electron accepting processes coexisted at several depth intervals. The viable metabolic diversity was only correlated with lithology or fracture in some paired samples; however, such correlation cannot be extrapolated to the whole core. It appears that organic carbon associated with sedimentary particulates was accessible to but not a limiting factor to microorganisms. Instead, the availability of electron acceptors regulated the expression of terminal electron accepting processes within a potentially isolated niche (e.g., pore space). Unlike other deep terrestrial subsurface ecosystems (Fennoscandian Shield, Lidy Hot springs, and South African Witwatersrand Basin) where inorganically-derived $\mathrm{H}_{2}$ plays an important role for autotrophic communities, the heterotrophic communities are fueled by photosynthetically-generated organic carbon stored in sedimentary strata in this ecosystem.

Acknowledgements This work was supported by NSC project grants to P. L. Wang, S. R. Song, H. T. Yu, and C. Y. Wang and by a distinguished postdoctoral fellowship to L. H. Lin. We also want to thank the TCDP drilling team and the sampling party for the assistance in field sampling, sample transportation and processing. Special thanks also to anonymous reviewers for providing considerable suggestions. This article is a TEC Contribution Number 00011.

\section{REFERENCES}

Boone, D. R., 1984: Propionate exchange reactions in methanogenic ecosystems. Appl. Environ. Microbiol., 48, 863-864.

Boone, D. R., R. L. Johnson, and Y. Liu, 1989: Diffusion of the interspecies electron carrier $\mathrm{H}_{2}$ and formate in methanogenic ecosystems and its implications in the measurement of $\mathrm{Km}$ for $\mathrm{H}_{2}$ or formate uptake. Appl. Environ. Microbiol., 55, 1735-1741.

Chang, T. W., 2005: Evolutionary analysis of subsurface microbial community in Taiwan Chelunpu Fault Zone. Master Thesis, National Taiwan University, 61 pp.

Chapelle, F. H., P. B. McMahon, N. M. Dubrovsky, R. F. Fujii, E. T. Oaksford, and D. A. Vroblesky, 1995: Deducing the distribution of terminal electron-accepting processes in hydrologically diverse groundwater system. Water Res. Res., 31, 359-371.

Chapelle, F. H., K. O’Neill, P. M. Bradley, B. A. Methe, S. A. Ciufo, L. L. Knobel, and D. R. Lovley, 2002: A hydrogen-based subsurface microbial community dominated by methanogens. Nature, 415, 312-315.

Coates, J. D., and L. A. Achenbach, 2002: The biogeochemistry of aquifer. In: Hurst, C. J., R. L. Crawford, M. J. McInerney, G. R. Knudsen, and L. D. Stetzenbach (Eds.), Manual 
of Environmental Microbiology, ASM Press, 719-727.

Cole, J., B. Chai, T. Marsh, R. Farris, Q. Wang, S. Kulan, S. Chandra, D. McGarrell, T. Schmidt, G. Garrity, and J. Tiedje, 2003: The Ribosomal Database Project (RDP-II): previewing a new autoaligner that allows regular updates and the new prokaryotic taxonomy. Nucl. Acids Res., 31, 442-443.

Colwell, F. S., 2001: Constraints on the distribution of microorganisms in subsurface environments. In: Fredrickson, J. K., and M. Fletcher (Eds.), Subsurface Microbiology and Biogeochemistry, Wiley, 71-96.

Cowen, J. P., S. J. Giovannoni, F. Kenig, H. P. Johnson, D. Butterfield, M. S. Rappe, M. Hutnak, and P. Lam, 2003: Fluids from aging ocean crust that support microbial life. Science, 299, 120-123.

D'Hondt, S., B. B. Jorgensen, D. J. Miller, A. Batzke, R. Blake, B. A. Cragg, H. Cypionka, G. R. Dickens, T. Ferdelman, K. U. Hinrichs, N. G. Holm, R. Mitterer, A. Spivack, G. Wang, B. Bekins, B. Engelen, K. Ford, G. Gettemy, S. D. Rutherford, H. Sass, C. G. Skilbeck, I. W. Aiello, G. Guerin, C. H. House, F. Inagaki, P. Meister, T. Naehr, S. Niitsuma, R. J. Parkes, A. Schippers, D. C. Smith, A. Teske, J. Wiegel, C. N. Padilla, and J. L. S. Acosta, 2004: Distributions of microbial activities in deep subseafloor sediments. Science, 306, 2216-2221.

Felsenstein, J., 1993: PHYLIP (Phylogeny inference package), ver. 3.5. University of Washington.

Fredrickson, J. K., and T. J. Phelps, 1996: Surface drilling and sampling. In: Hurst, C. J., G. R. Knudsen, M. J. McInerney, L. D. Stetzenbach, and M. V. Walter (Eds), Manual of Environmental Microbiology, Am. Soc. Microbiol., 526-540.

Fredrickson, J. K., J. M. Zachara, D. W. Kennedy, H. Dong, T. C. Onstott, N. W. Hinman, and S. M. Li, 1998: Biogenic iron mineralization accompanying the dissimilatory reduction of hydrous ferric oxide by a groundwater bacterium. Geochim. Cosmochim. Acta, 62, 3239-3257.

Fredrickson, J. K., and T. C. Onstott, 2001: Biogeochemical and geological significance of subsurface microbiology. In: Fredrickson, J. K., and M. Fletcher (Eds.), Subsurface Microbiology and Biogeochemistry, Wiley, 3-37.

Hall, T. A., 1999: BioEdit: A user-friendly biological sequence alignment editor and analysis program for Windows 95/98/NT. Nucl. Acids. Symp. Ser., 41, 95-98.

Haneberg, W. C., P. S. Mozley, J. C. Moore, and L. B. Goodwin, 1999: Faults and subsurface fluid flow in the shallow crust. In Geophysical Monograph, AGU, 113, 222 pp.

Haveman, S. A., and K. Pedersen, 1999: Distribution and metabolic diversity of microorganisms in deep igneous rock aquifers of Finland. Geomicrobiol. J., 16, 277-294.

Hoehler, T. M., M. J. Alperin, D. B. Albert, and C. S. Martens, 2001: Apparent minimum free energy requirements for methanogenic Archaea and sulfate-reducing bacteria in an anoxic marine sediment. FEMS Microbiol. Ecol., 38, 33-41.

Hung, J. H., Y. H. Wu, E. C. Yeh, J. C. Wu, and TCDP Scientific Party, 2007: Subsurface structure, physical properties, and fault zone characteristics in the scientific drill holes of Taiwan Chelungpu-fault Drilling Project. Terr. Atmos. Ocean. Sci., 18, 271-293, doi: 10.3319/TAO.2007.18.2.271(TCDP). 
Jackson, B. E., and M. J. Mclnerney, 2002: Anaerobic microbial metabolism can proceed close to thermodynamic limits. Nature, 415, 454-456.

Lane, D. J., 1991: 16S/23S rRNA sequencing. In: Stackenbrandt, E., and M. Goodfellow (Eds.), Nucleic Acid Techniques in Bacterial Systematics, Wiley, 115-175.

Lin, L. H., J. Hall, J. Lippmann, J. A. Ward, B. Sherwood Lollar, M. DeFlaun, R. Rothmel, D. P. Moser, T. Gihring, B. Mislowack, and T. C. Onstott, 2005a: Radiolytic $\mathrm{H}_{2}$ in continental crust: Nuclear power for deep subsurface microbial communities. Geosyst. Geochem. Geophy., doi:10.1029/2004GC000907.

Lin, W., E. C. Yeh, T. Hirono, W. Soh, M. Takahashi, C. Y. Wang, K. F. Ma, J. H. Hung, and S. R. Song, 2005b: Preliminary measurement results of pore size distribution of sedimentary rocks retrieved from TCDP Hole A. Abstract with program for Annual Meeting of Geological Society of China.

Lonergan, D. J., H. L. Jenter, J. D. Coates, E. P. Phillips, T. M. Schmidt, and D. R. Lovlet, 1996: Phylogenetic analysis of dissimilarotry Fe(III)-reducing bacteria. J. Bacteriol., 178, 2402-2408.

Lovley, D. R., and E. J. P. Phillips, 1987: Rapid assay for microbially reducible ferric iron in aquatic sediments. Appl. Environ. Microbiol., 53, 1536-1540.

Lovley, D. R., and S. Goodwin, 1988: Hydrogen concentrations as an indicator of the predominant terminal electron-accepting reaction in aquatic sediments. Geochim. Cosmochim. Acta, 52, 2993-3003.

Lovley, D. R., and R. T. Anderson, 2000: Influence of dissimilatory metal reduction on fate of organic and metal contaminants in the subsurface. Hydrogeol. J., 8, 77-88.

McMahon, P. B., and F. H. Chapelle, 1991: Microbial production of organic acids in aquitard sediments and its role in aquifer geochemistry. Nature, 349, 233-235.

Meijer, W. G., M. E. Nienhuis-Kuiper, and T. A. Hanse, 1999: Fermentative bacteria from estuarine mud: phylogenetic position of Acidaminobacter hydrogenoformans and description of a new type of Gram-negative, propionigenic bacterium as Propionibacter pelophilus gen. nov., sp. nov. Int. J. Syst. Bacteriol., 49, 1039-1044.

Onstott, T. C., T. J. Phelps, F. S. Colwell, D. Ringeberg, D. C. White, and D. R. Boone, 1998: Observations pertaining to the origin and ecology of microorganisms recovered from the deep subsurface of Taylorsville basin, Virginia. Geomicrobiol. J., 15, 353-385.

Onstott, T. C., D. P. Moser, S. M. Pfiffner, J. K. Fredrickson, F. J. Brockman, T. J. Phelps, D. C. White, A. Peacock, D. Balkwill, R. Hoover, L. R. Krumholz, M. Borscik, T. L. Kieft, and R. Wilson, 2003: Indigenous and contaminant microbes in ultradeep mines. Environ. Microbiol., 5, 1169-1191.

Onstott, T. C., L. H. Lin, M. Davidson, B. Mislowack, M. Borcsik, J. Hall, G. Slater, J. Ward, B. Sherwood Lollar, J. Lippmann-Pike, E. Boice, L. Pratt, S. Pfiffner, D. P. Moser, T. Gihring, T. L. Kieft, T. Phelps, E. Vanherden, D. Litthaur, M. DeFlaun, and R. Rothmel, 2006: The origin and age of biogeochemical trends in deep fracture water of the Witwatersrand Basin, South Africa. Geomicrobiol. J., 23, 369-414.

Parkes, R. J., B. A. Cragg, and P. Wellsbury, 2000: Recent studies on bacterial populations and processes in subseafloor sediments: A review. Hydrogeol. J., 8, 11-28.

Pedersen, K., 1997: Microbial life in deep granitic rock. FEMS Microbiol. Rev., 20, 399-414. 
Pedersen, K., L. Hallbeck, J. Arlinger, A. C. Erlandson, and N. Jahromi, 1997: Investigation of the potential for microbial contamination of deep granitic aquifers during drilling using 16S rRNA gene sequencing and culturing methods. J. Microbiol. Meth., 30, 179-192.

Pedersen, K., 2001: Diversity and activity of microorganisms in deep igneous rock aquifer of the Fennoscandian shield. In: Fredrickson, J. K., and M. Fletcher (Eds.), Subsurface Microbiology and Biogeochemistry, Wiley-Liss, 97-140.

Schink, B., and M. Stieb, 1983: Fermentative degradation of polyethyleneglycol by a new strictly anaerobic, Gram-negative, non-spore forming bacterium, Pelobacter venetianus sp. nov. Appl. Environ. Microbiol., 45, 1905-1913.

Schink, B., 1984: Fermentation of 2, 3-butanediol by Pelobacter carbinolicus sp. nov. and Pelobacter propionicus sp. nov., and evidence for propionate formation from $\mathrm{C} 2-$ compounds. Arch. Microbiol., 137, 33-41.

Schink, B., 1985: Fermentation of acetylene by an obligate anaerobe, Pelobacter acetylenicus sp. nov. Arch. Microbiol., 142, 295-301.

Smith, D. C., A. J. Spivack, M. R. Fisk, S. A. Haveman, H. Staudigel, and Ocean Drilling Program Leg 185 Ship Board Scientific Party, 2000: Tracer-based estimates of drilling-induced microbial contamination of deep sea crust. Geomicrobiol. J., 17, 207-219.

Smith, R. L., 2002: Determining the terminal electron-accepting reaction in the saturated subsurface. In: Hurst, C. J., R. L. Crawford, M. J. McInerney, G. R. Knudsen, and L. D. Stetzenbach (Eds.), Manual of Environmental Microbiology, ASM Press, 743-752.

Song, S. R., L. W. Kuo, E. C. Yeh, C. Y. Wang, J. H. Hung, and K. F. Ma, 2007: Characteristics of the lithology, fault-related rocks and fault zone structures in TCDP Hole-A. Terr. Atmos. Ocean. Sci., 18, 243-269, doi: 10.3319/TAO.2007.18.2.243(TCDP).

Stevens, T. O., and J. P. McKinley, 1995: Lithoautotrophic microbial ecosystems in deep basalt aquifers. Science, 270, 450-454.

Suppe, J., 1981: Mechanisms of mountain building in Taiwan. Memoir Geol. Soc. China, 4, 67-89.

Teng, L. S., C. T. Lee, Y. B. Tsai, and L. Y. Hsiao, 2000: Slab breakoff as a mechanism for flipping of subduction polarity in Taiwan. Geology, 28, 155-158.

Torgersen, T., and W. B. Clarke, 1985: Helium accumulation in groundwater, I: An evaluation of sources and the continental flux of crustal ${ }^{4} \mathrm{He}$ in the Great Artesian Basin, Australia. Geochim. Cosmochim. Acta, 49, 1211-1218.

Wang, C. Y., C. H. Chang, and H. Y. Yen, 2000: An interpretation of the 1999 Chi-Chi earthquake in Taiwan based on the thin-skinned thrust model. Terr. Atmos. Ocean. Sci., 11, 609-630.

Whitman, W. B., D. C. Coleman, and W. J. Wiebe, 1998: Prokaryotes: The unseen majority. Proc. Natl. Acad. Sci., 95, 6578-6583.

Yeh, E. C., H. Sone, T. Nakaya, K. H. Ian, S. R. Song, J. H. Hung, W. Lin, T. Hirono, C. Y. Wang, K. F. Ma, W. Soh, and M. Kinoshita, 2007: Core description and characteristics of fault zones from Hole-A of the Taiwan Chelungpu-fault Drilling Project. Terr. Atmos. Ocean. Sci., 18, 327-357, doi: 10.3319/TAO.2007.18.2.327(TCDP).

Yu, S. B., H. Y. Chen, and L. C. Kuo, 1997: Velocity field of GPS stations in the Taiwan area. Tectonophysics, 274, 41-59. 
Zhang, G., H. Dong, Z. Xu, D. Zhao, and C. Zhang, 2005: Microbial diversity in ultra-highpressure rocks and fluids from the Chinese Continental Scientific Drilling Project in China. Appl. Environ. Microbiol., 71, 3213-3227.

Zinder, S. H., 1993: Physiological ecology of methanogens. In: Ferry, J. G. (Ed), Methanogenesis, Chapman \& Hall, 128-206.

Wang, P. L., L. H. Lin, H. T. Yu, T. W. Cheng, S. R. Song, L. W. Kuo, E. C. Yeh, W. Lin, and C. Y. Wang, 2007: Cultivation-based characterization of microbial communities associated with deep sedimentary rocks from Taiwan Chelungpu Drilling Project cores. Terr. Atmos. Ocean. Sci., 18, 395-412, doi: 10.3319/TAO.2007.18.2.395(TCDP). 